\title{
Penerapan Intelegensi Buatan Dengan Algoritma Negamax pada Aplikasi Permainan Deret Lima
}

\author{
Ridwanto Salmon Aruan ${ }^{1}$, Imron Nugraha ${ }^{2}$, Saharudin ${ }^{3}$ \\ 1,2,3 Jurusan Teknik Informatika STT Indonesia Tanjungpinang \\ Jln. Pompa Air No. 28 Tanjungpinang Kepulauan Riau Indonesia \\ ${ }^{1}$ rasalmon26@gmail.com \\ 2imron_nugraha05@yahoo.com \\ ${ }^{3}$ saharoedin.official@gmail.com
}

\begin{abstract}
Intisari- Perkembangan teknologi semakin pesat, termasuk perkembangan di dunia hiburan digital dalam hal ini perkembangan permainan berbasis komputer. intelegensia buatan adalah merupakan bagian dari kemajuan teknologi itu sendiri yang membuat mesin atau komputer dapat melakukan pekerjaan seperti dan sebaik manusia dimana komputer dapat berfikir selayaknya manusia, dalam dunia permainan komputer pun demikian, komputer dapat berpikir selayaknya manusia dalam melakukan permainan. Permainan deret lima yang menerapkan perkembangan teknologi permainan digital berbasis komputer dengan menggunakan Intelegensi buatan dengan algoritma negamax membentuk komputer dapat bermain, berpikir selayaknya manusia dalam menyusun bola berderet sebanyak lima buah secara horizontal, vertikal, maupun diagonal dimana komputer dapat mengalahkan manusia dalam bermain. Permainan deret lima merupakan tipe permainan simetris, yang menggunakan papan berpetak dalam permainannya. Pemain akan menyusun bola berwarna putih dan hitam sebanyak lima buah secara berderet baik horizontal, vertikal, maupun diagonal di papan permainan. Pemain yang terlebih dahulu dapat menyusun bola itu yang memenangkan permainan.
\end{abstract}

Kata kunci- Intelegensi Buatan, Algoritma Negamax .

Abstract - The development of technology is growing rapidly, including developments in the world of digital entertainment, in this case the development of computer-based games. Artificial intelligence is part of technological advancement itself that makes machines or computers able to do work like and as well as humans where computers can think like humans, in the world of computer games too, computers can think like humans in playing games. The five-line game that applies the development of computer-based digital game technology using artificial intelligence with the Negamax algorithm to form computers can play, thinking like humans in arranging five balls in a row horizontally, vertically, or diagonally where computers can beat humans in playing The fifth line game is a symmetrical type of game, which uses a checkerboard in its game. Players will arrange five white and black balls in a row either horizontally, vertically or diagonally on the game board. The player who can arrange the balls first wins the game.

Keywords- Artificial Intelligence, Negamax Algorithm.

\section{Pendahuluan}

Perkembangan teknologi di era globalisasi saat ini semakin pesat dan sangat dibutuhkan hampir di semua bidang dimana semua orang dapat terhubung dengan mudah, cepat, dan efisien, sehingga semakin menuntut setiap masyarakat dunia untuk mengikuti perkembangan teknologi. Atas kemajuan teknologi komputer ini pun banyak membantu manusia dalam bekerja bahkan kemampuan teknologi komputer dapat menyaingi kemampuan manusia itu sendiri.

Kecerdasan/intelegensi buatan adalah merupakan bagian dari kemajuan teknologi itu sendiri yang membuat mesin atau komputer dapat melakukan pekerjaan seperti dan sebaik manusia dimana komputer dapat berpikir selayaknya manusia. Kecerdasan/intelegensi buatan dapat diterapkan dalam berbagai bidang seperti Sistem Pakar (Expert System), Pengolahan Bahasa Alami (Natural Language Processing), Pengenalan Ucapan (Speech Recognition), Robotika dan Sistem Sensor, Computer vision, serta yang paling menarik adalah penerapannya dalam permainan (game).

Pembuatan aplikasi kecerdasan/intelegensi buatan dalam bidang permainan sangat berguna bagi manusia tidak hanya sekedar hiburan dalam mengisi waktu luang, namun dapat juga membantu manusia untuk mengasah kecerdasan, meningkatkan kreativitas, dan belajar mengelola emosi. Sehingga pengguna dari aplikasi permainan tidak hanya pada kalangan anak-anak saja, tapi kalangan dewasa juga. Aplikasi permainan pun sangat pesat dan memiliki pasar sendiri di dunia industri, sebut saja pokemon go dan Clash of Clans yang sempat ramai di masyarakat.

Ada banyak aplikasi permainan dibuat dengan prinsip intelegensia buatan atau Artificial Intelligence (AI) dari game yang sederhana sampai yang rumit. Dalam pembuatan aplikasi permainan dengan prinsip intelegensia buatan digunakan berbagai macam algoritma pemrograman diantaranya minimax, negamax, dan alpha-beta. Pengembangan game itu sendiri masih banyak dikembangkan oleh para peneliti, programmer, maupun ilmuwan dengan memanfaatkan penggunaan algoritma pemrograman tersebut. Dari penelitian yang sudah ada maka penulis tertarik untuk melakukan pengembangan intelegensia buatan dalam sebuah permainan sederhana dengan pemanfaat algoritma negamax dengan judul "Penerapan Intelegensia Buatan Dengan Algoritma Negamax Pada Aplikasi Permainan Deret Lima". 


\section{Metodologi Penelitian}

\section{A. Metode Pengumpulan Data}

Metode pengumpulan data yang digunakan dalam pembuatan laporan Skripsi adalah :

1) Studi Pustaka Studi pustaka dilakukan dengan caracara mempelajari teori-teori, buku-buku, dan sumbersumber lain yang berhubungan dengan objek permasalahan yang dibahas.

2) Observasi Observasi melakukan pengamatan langsung terhadap objek yang diteliti untuk mendapatkan data dan informasi yang diperlukan sesuai dengan permasalahan.

\section{B. Metode Pengembangan Sistem}

Dalam pelaksanaannya proses tugas akhir perlu dilakukan pengembangan sistem, perancangan ini membutuhkan sebuah metodologi sebagai pedoman bagaimana dan apa yang harus dilakukan selama mengembangkan sistem. Metode pengembangan sistem yang digunakan adalah Metode Spiral. Model spiral adalah proses perangkat lunak yang evolusioner yang merangkai sifat iteratif dari prototipe dengan cara kontrol dan aspek sistematis dari model sekuensial linier. Model yang awalnya diusulkan oleh Boehm ini memiliki potensi untuk pengembangan pertambahan perangkat lunak secara cepat. Tahapan-tahapan kegiatannya adalah sebagai berikut :

1) Komunikasi pelanggan : Tugas- tugas yang dibutuhkan untuk membangun komunikasi yang efektif di antara pengembang dan pelanggan.

2) Perencanaan : Tugas-tugas yang dibutuhkan untuk mendefinisikan sumber-sumber daya, ketepatan waktu, dan proyek informasi lain yang berhubungan.

3) Analisis resiko : Tugas-tugas yang dibutuhkan untuk menafsirkan resiko-resiko, baik manajemen maupun teknis.

4) Perekayasaan : Tugas-tugas yang dibutuhkan untuk membangun satu atau lebih representasi dari aplikasi tersebut.

5) Konstruksi dan peluncuran : Tugas-tugas yang dibutuhkan untuk mengkonstruksi, menguji, memasang (instal) dan memberikan pelayanan kepada pemakai (contohnya pelatihan dan dokumentasi).

6) Evaluasi pelanggan : Tugas-tugas yang dibutuhkan untuk memperoleh umpan balik dari pelanggan dengan didasarkan pada evaluasi representasi perangkat lunak, yang dibuat selama masa perekayasaan, dan implementasi selama masa pemasangan.

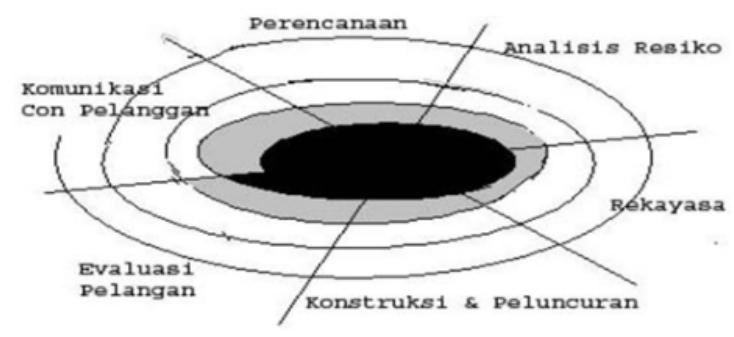

Gambar 2.1 Model Spiral Tipikal[1]

\section{KAJIAN PUSTAKA}

\section{A. Intelegensia Buatan}

Intelegensia buatan atau yang juga disebut kecerdasan buatan yang dalam bahasa inggrisnya Artificial Intelligence (AI) merupakan bagian dari kemajuan perkembangan teknologi komputer yang sangat membantu manusia dalam melakukan aktifitasnya, dimana mesin (komputer) dapat melakukan aktifitas, berfikir selayaknya manusia. Kecerdasan buatan menurut Paul Y. Gloess, adalah ilmu yang mempelajari bagaimana suatu mesin seolah-olah memiliki kecerdasan dalam memecahkan suatu masalah yang diberikan kepadanya[2].

Beberapa definisi intelegensia buatan (AI) menurut para ahli diantaranya:

1) Schalkoff (1990). AI adalah bidang studi yang berusaha menerangkan dan meniru perilaku cerdas dalam bentuk proses komputasi. Rich dan Knight (1991). AI adalah studi tentang cara membuat komputer melakukan sesuatu yang, sampai saat ini, orang dapat melakukannya lebih baik.

2) Luger dan Stubblefield (1993). AI adalah cabang ilmu komputer yang berhubungan dengan otomasi perilaku yang cerdas.

3) Haag dan Keen (1996). AI adalah bidang studi yang berhubungan dengan penangkapan, pemodelan, dan penyimpanan kecerdasan manusia dalam sebuah sistem teknologi informasi sehingga sistem tersebut dapat memfasilitasi proses pengambilan keputusan yang biasanya dilakukan oleh manusia[].

\section{B. Pengertian Algoritma}

Abu Ja'far Muhammad Ibnu Musa Al-Khawarizmi, penulis buku "Aljabar wal muqabala" pada abad ke-9 dianggap sebagai pencetus pertama Algoritma karena di dalam buku tersebut beliau menjelaskan langkah langkah dalam menyelesaikan berbagai persoalan aritmatika (aljabar), kemungkinan besar kata "Algoritma" yang kemungkinan berubah menjadi "Algorism" selanjutnya menjadi "Algorithm".

Ada beberapa definisi tentang algoritma menurut para ahli, diantaranya sebagai berikut:

1) Teknik penyusunan langkah-langkah penyelesaian masalah dalam bentuk kalimat dengan jumlah kata terbatas, tetapi tersusun secara logis dan sistematis. 
2) Suatu prosedur yang jelas untuk menyelesaikan suatu persoalan dengan menggunakan langkah-langkah tertentu dan terbatas jumlahnya.

3) Algoritma adalah deretan langkah-langkah komputasi yang mentransformasikan data masukan menjadi keluaran.

4) Algoritma adalah deretan yang menjelaskan untuk memecahkan masalah, yaitu untuk memperoleh keluaran yang diinginkan dari suatu masukan dalam jumlah waktu yang terbatas.

5) Algoritma adalah prosedur komputasi yang terdefinisi dengan baik yang menggunakan beberapa nilai sebagai masukan dan menghasilkan beberapa nilai yang disebut keluaran.

Menurut Donald E. Knuth dalam bukunya yang berjudul The Art of computer programming [KNU 73], algoritma harus memiliki lima ciri penting sebagai berikut:

1) Algoritma harus berhenti setelah mengerjakan sejumlah langkah terbatas.

2) Setiap langkah harus didefinisikan dengan tepat dan tidak berarti-dua (ambiguous).

3) Algoritma memiliki nol atau lebih masukan (input). Masukan ialah besaran yang diberikan algoritma untuk di proses.

4) Algoritma memiliki nol atau lebih keluaran (output). Keluaran dapat berupa pesan atau besaran yang memiliki hubungan dengan masukan.

5) Algoritma harus sangkil (effective). Setiap langkah harus sederhana sehingga dapat dikerjakan dalam jumlah waktu yang masuk akal.

\section{Algoritma Negamax}

Algoritma Negamax merupakan bentuk varian dari algoritma minimax yang bergantung pada zero-sum game (permainan kompetisi). Perbedaan dari algoritma negamax dan minimax adalah negamax hanya menggunakan fungsi maksimal dan tidak seperti algoritma minimax yang menggunakan kedua fungsi yaitu fungsi maksimal dan fungsi minimal. Ini dapat dilakukan dengan menegasikan nilai yang dikembalikan dari point lawan daripada mencari nilai minimal, sehingga dapat dikatakan negamax adalah penyederhanaan implementasi minimax. Hal ini dapat ditunjukan dengan menggunakan relasi matematika berikut:

$$
\operatorname{Max}(\mathbf{a}, \mathbf{b})==-\operatorname{Min}(-\mathbf{a},-\mathbf{b})
$$

Kelebihan negamax dibanding algoritma adversarial search yang lain adalah algoritma negamax lebih sederhana dan hasil optimal oleh karena itu negamax dipandang dapat menghasilkan solusi yang optimal yang dapat diimplementasikan pada pemain komputer dalam permainan deret lima.

\section{Permainan Deret Lima}

Permainan yang terbentuk dari kata dasar 'main' yaitu melakukan permainan untuk menyenangkan hati (dengan menggunakan alat-alat tertentu atau tidak). Sedang kan Permainan atau Gim merupakan sebuah aktivitas rekreasi dengan tujuan bersenang-senang, mengisi waktu luang, atau berolahraga ringan. Permainan biasanya dilakukan sendiri atau bersama-sama (kelompok)[].

Ide dasar dari permainan deret lima ini yaitu permainan TacTic-Toc, atau yang dikenal di Indonesia catur jawa yang biasa dimainkan oleh anak-anak, dimana teknik permainannya pemain harus membuat garis tanpa putus secara vertikal, horizontal maupun diagonal dengan batu ataupun daun sebanyak tiga buah. Sedangkan pada permainan deret lima ini pemain akan menyusun batu sebanyak lima buah di dalam papan permainan berskala 15 X 15 secara vertikal, horizontal, maupun diagonal, pemain yang pertama kali menyusun deretan sebanyak lima buah dia yang menjadi pemenang. Berikut teknik permainannya:

1) Pemilihan objek yang digunakan dalam permainan menggunakan bola berwarna yang harus disuse sebanyak 5 buah secara berederatan baik secara horizontal, vertikal, maupun diagonal di papan berskala 15 X 15 .

2) Pemain bebas meletakan bola dimana saja atau bebas menjalankan strateginya.

3) Permainan dimainkan oleh dua pemain yang dimainkan secara bergantian.

4) Penyusunan bola harus tersusun sejajar membentuk garis lurus tanpa putus.

5) Setiap pemain akan di berikan waktu sebanyak 15 detik untuk berpikir, menyusun bola maupun menghambat lawan dalam menyusun bola.

6) Apabila waktu yang berikan sudah habis namun pemain juga tidak melakukan permainan maka pihak lawan yang menang.

\section{E. Konsep Dasar OOP (Object Oriented Programming)}

OOP (Object Oriented Programming) atau pemrograman berorientasi objek adalah suatu cara baru dalam berpikir serta berlogika dalam menghadapi masalh-masalah yang akan dicoba-atasi dengan bantuan komputer. OOP tidak seperti pendahulunya (pemrograman terstruktur), mencoba melihat permasalahan lewat pengamatan dunia nyata dimana setiap objek adalah entitas tunggal yang memiliki kombinasi struktur data dan fungsi tertentu. Ini kontras dengan pemrograman terstruktur dimana struktur data dan fungsi didefinisikan secara terpisah dan tidak berhubungan secara erat.

Pada perkembangannya, filosofi OOP menciptakan sinergi yang luar biasa sepanjang siklus pengembangan perangkat lunak (perencanaan, analisis, perancangan, implementasi serta pengujian) sehingga dapat diterapkan pada perancangan sistem secara umum, menyangkut perangkat lunak, perangkat keras, serta sistem informasi secara keseluruhan[].

\section{F. UML (Unified Modelling Language)}

UML (Unified Modelling Language) adalah salah satu alat bantu yang sangat handal di dunia pengembangan sistem yang berorientasi objek. Hal ini disebabkan karena UML menyediakan Bahasa pemodelan visual yang memungkinkan 
bagi pengembang system untuk membuat cetak biru atas visi mereka dalam bentuk yang baku, mudah dimengerti serta dilengkapi dengan mekanisme yang efektif untuk berbagi (sharing) dan mengkomunikasikan rancangan mereka dengan yang lain[].

UML merupakan kesatuan dari bahasa pemodelan yang dikembangkan oleh Booch, Object Modelling Technique (OMT) dan Object Oriented Software Engineering (OOSE). Dengan UML, metode Booch, OMT, OOSE digabungkan dengan membuang elemen-elemen yang tidak praktis ditambah dengan elemen-elemen dari metode lain yang lebih efektif dan elemen-elemen baru yang belum ada pada metode terdahulu sehingga UML lebih ekspresif dan seragam daripada metode lainnya.

\section{HASIL DAN PEMBAHASAN}

\section{A. Analisis Permainan Yang Akan Dibangun}

Permainan yang akan dibangun yaitu permainan bergenre strategi dengan karakter bola hitam dan putih yang mewakili masing-masing pemain, setiap pemain diberi kesempatan waktu untuk bermain menentukan strategi meletakkan bola dan bebas meletak bola dimana saja di daerah papan permainan yang berskala $15 \times 15$ untuk menyusun deret maupun menghambat jalannya lawan dalam menyusun bola.

Permainan strategi menyusun bola berderet sebanyak lima buah ini diharapkan dapat meningkatkan kreatifitas, melatih mental dan emosi, meningkatkan daya analisa maupun hiburan bagi pemainnya.

\section{B. Analisa Penggunaan Algoritma Negamax}

Algoritma Negamax digunakan untuk melakukan perkiraan langkah berikutnya. Fungsi ini digunakan oleh prosedur gerakan komputer. Algoritma negamax hanya menggunakan fungsi maksimal dan tidak seperti algoritma minimax yang menggunakan kedua fungsi yaitu fungsi maksimal dan fungsi minimal. Ini dapat dilakukan dengan menegasikan nilai yang dikembalikan dari point lawan daripada mencari nilai minimal, sehingga dapat dikatakan negamax adalah penyederhanaan implementasi minimax. Kelebihan negamax dibanding algoritma adversarial search yang lain adalah algoritma negamax lebih sederhana dan hasil optimal oleh karena itu negamax dipandang dapat menghasilkan solusi yang optimal yang dapat diimplementasikan pada pemain komputer dalam permainan deret lima.

Beberapa alasan penulis menggunakan algoritma negamax, antara lain:

1) Algoritma negamax banyak digunakan pada aplikasi permainan simetris.

2) Operasi logika dan aritmatika sederhana dan tidak terlalu banyak.

3) Setiap keputusan langkah yang dilakukan pemain (manusia) belum tentu menjadi langkah yang terbaik untuk memenangkan dalam permainan.

Dengan alasan diatas maka penulis menggunakan algoritma negamax untuk membangun aplikasi permainan deret lima untuk menentukan langkah yang akan dilakukan oleh komputer.

\section{Perancangan Use Case Diagram}

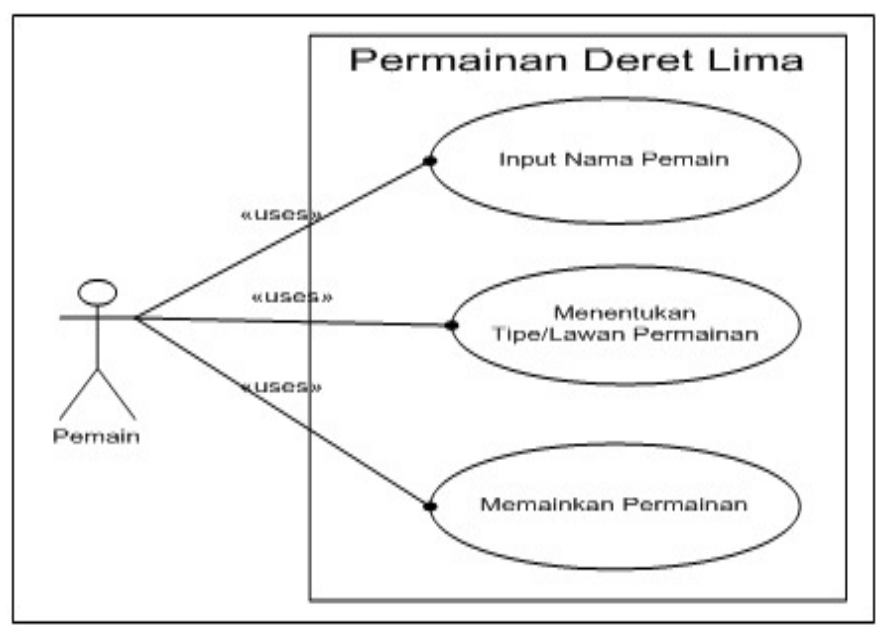

Gambar 4.1 Use Case Diagram Permainan Deret Lima

\section{Activity Diagram}

Activity Diagram atau diagram aktivitas adalah bentuk visual dari alir kerja yang berisi aktivitas dan tindakan yang dapat juga berisi pilihan, pengulangan, dan concurrency. Dalam Unified Modelling Language, diagram aktivitas dibuat untuk menjelaskan aktifitas komputer sebagai respons yang dilakukan yang dilakukan pengguna dalam sistem. Berikut aktivitas diagram dari aplikasi permainan deret lima:

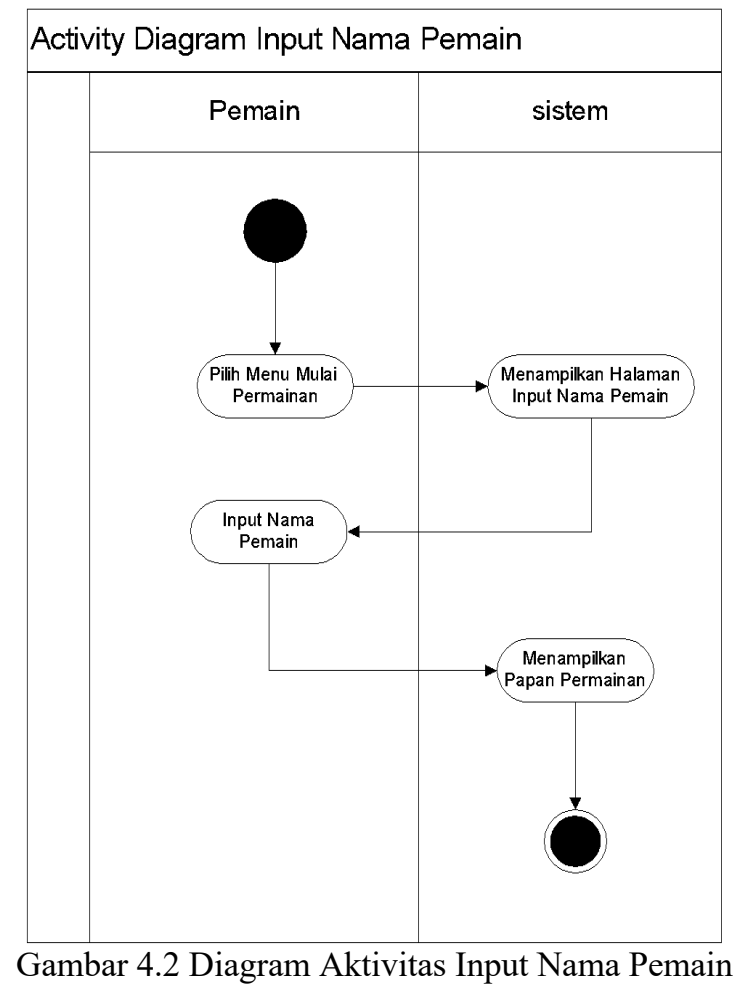


Dari diagram aktivitas diatas dapat dijelaskan bahwa ketika pemain memilih menu Mulai permainan, maka sistem akan menampilkan halaman untuk menginputkan nama pemain, setelah pemain mengunputkan namanya maka system akan menampilkan papan permainan.

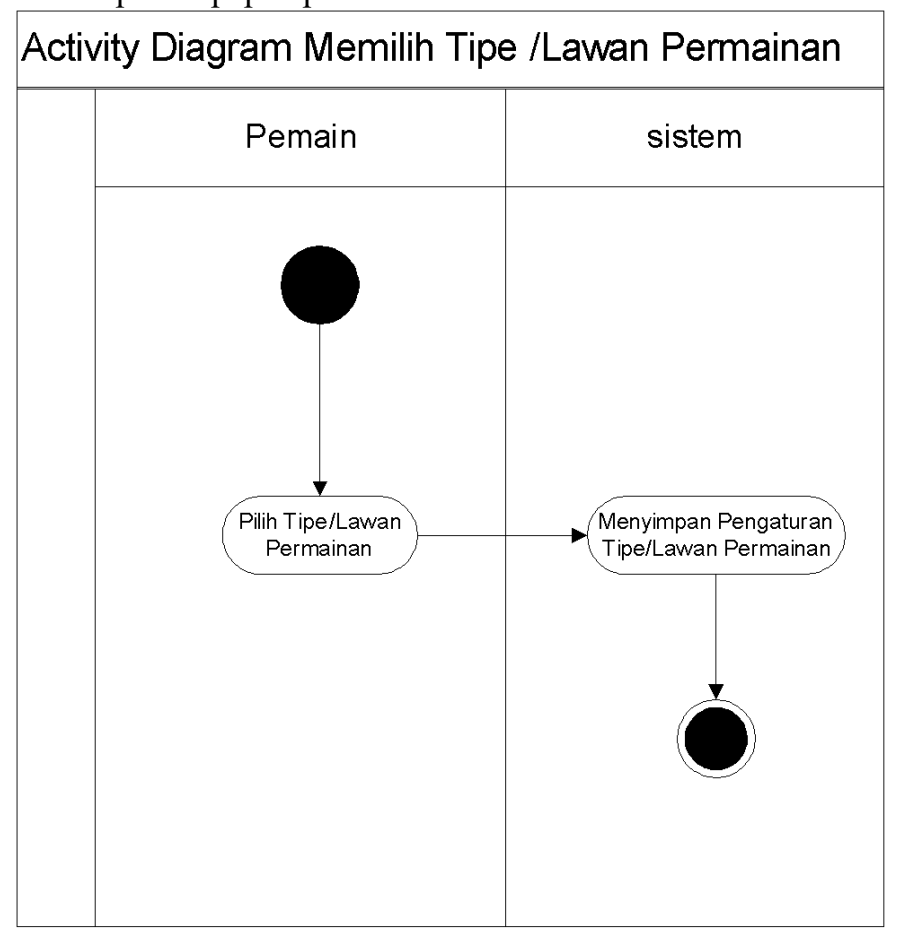

Gambar 4.3 Diagram Aktivitas Memilih Tipe/Lawan Permainan

Penjelasan diagram aktivitas di atas sebelum melakukan permainan pemain terlebih dahulu untuk memilih tipe/lawan dalam permainan, adapun tipe/lawan dalam permainan deret lima yaitu pemain/manusia melawan komputer pada tipe ini pemain dapat mengatur siapa yang terlebih dahulu melakukan permainan baik komputer terlebih dahulu maupun pemain, manusia melawan manusia, dan komputer melawan komputer pada tipe ini komputer dapat memainkan permainan tanpa adanya perintah dari manusia.

\section{E. Sequence Diagram}

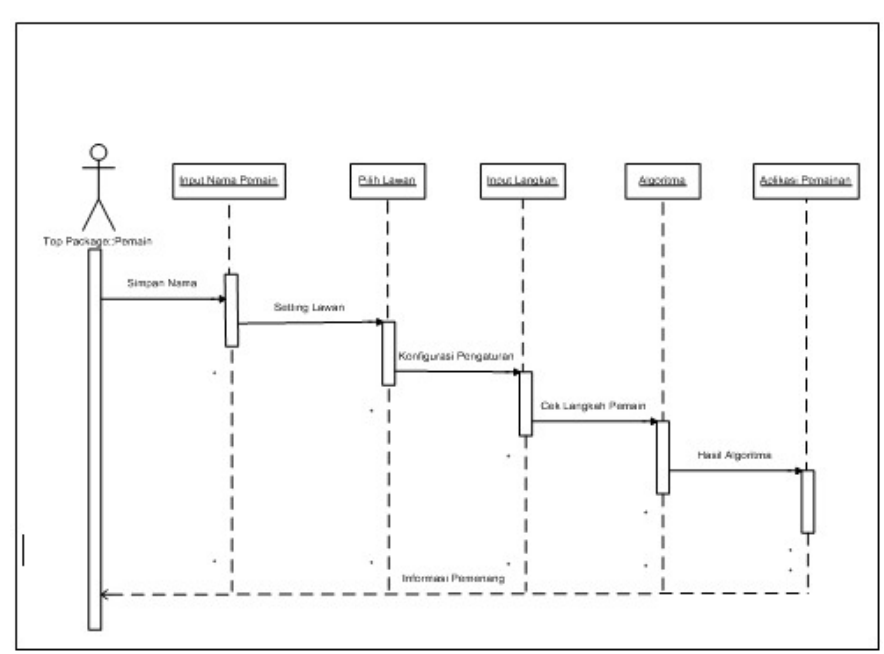

Gambar 4.4 Sequence Diagram Permainan Deret Lima

Dari Gambar 4.4 Sequence Diagram Permainan Deret Lima diatas dapat dijelaskan bahwa pemain terlebih dahulu melakukan inputan nama untuk masuk ke papan permainan, dan kemudian melakukan pengaturan terhadap permainan yakni memilih lawan dalam bermain dan sistem akan mengkonfigurasinya untuk dapat memulai permainan dengan menginput langkah guna membentuk deretan bola maupun menghadang langkah lawan. Inputan langkah yang dilakukan masing-masing tiap pemain akan di cek melalui algoritma yang digunakan apakah langkah-langkah tersebut sudah membentuk sebuah deretan garis lurus bola sebanyak lima buah. Dari pengecekan melalui algoritma maka sistem akan memberitahukan hasil perhitungan langkah dan memberikan informasi hasil akhir dari permainan siapa yang menjadi pemenang melalui kontak pesan yang muncul.

\section{F. Class Diagram}

Class Diagram atau diagram kelas adalah diagram UML yang menggambarkan kelas-kelas dalam sebuah sistem dan hubungannya antara satu dengan yang lain, serta dimasukkan pula atribut dan operasinya. Berikut dibawah ini class diagram pada permainan deret lima:

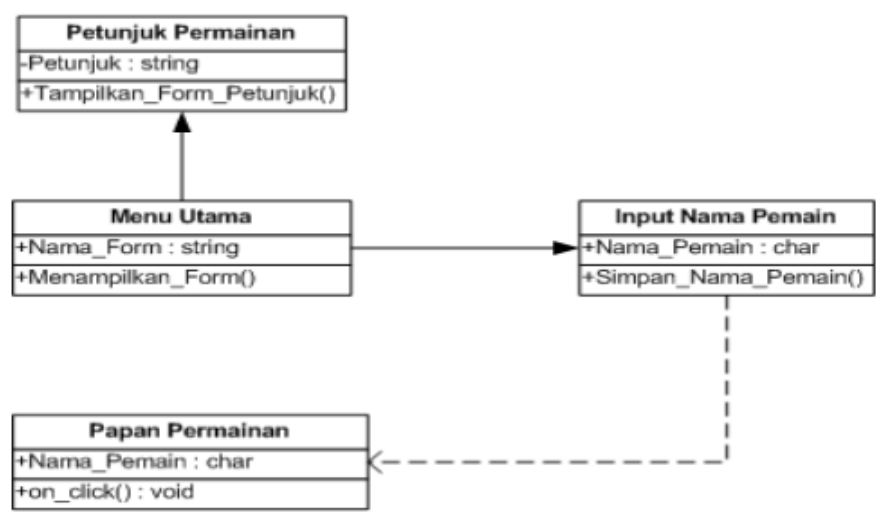

Gambar 4.5 Class Diagram Permainan Deret Lima 
Permainan Deret Lima diatas dapat dijelaskan bahwa permainan deret lima terdiri dari 5 (lima) kelas yaitu kelas Menu utama yang memiliki operasi untuk menampilkan Kelas atau form Input Nama Pemain, kelas atau form Petunjuk Permainan, yang memiliki atribut dari nama form. Jenis visibility yang digunakan yaitu public yang ditandai dengan simbol '+', yang artinya semua kelas serta objek diluar kelas yang bersangkutan dapat menggunakan/mengakses atribut serta operasi yang dideklarasikan sebagai public. Kelas Input Nama Pemain memiliki atribut nama pemain dengan tipe data char dan memiliki operasi menyimpan nama pemain yang diinputkan, Kelas Papan Permainan memiliki relasi ketergantungan/dependency hubungan dimana perubahan pada suatu kelas akan mempengaruhi kelas yang lain, pada aplikasi ini terhadap kelas Input Nama Pemain yang ditandai simbol '-->' Kelas Petunjuk Permainan memiliki operasi untuk menampilkan petunjuk dari permainan deret lima, dengan atribut Petunjuk tipe data string menggunakan visibility private yang ditandai dengan simbol '-' yang artinya hanya kelas itu sendiri yang dapat menggunakannya.

\section{G. Flowchart Diagram}

Flowchart diagram menjelaskan siklus dari semua kegiatan komputer mulai dari input (masukan) yakni berupa nama pemain, inputan langkah, proses algoritma untuk menghitung jumlah deretan bola yang disusun setiap pemain, sampai mendapatkan hasil output (keluaran) berupa informasi pemenang dalam permainan yakni nama pemain. Berikut dibawah ini flowchart diagram dalam permainan deret lima.

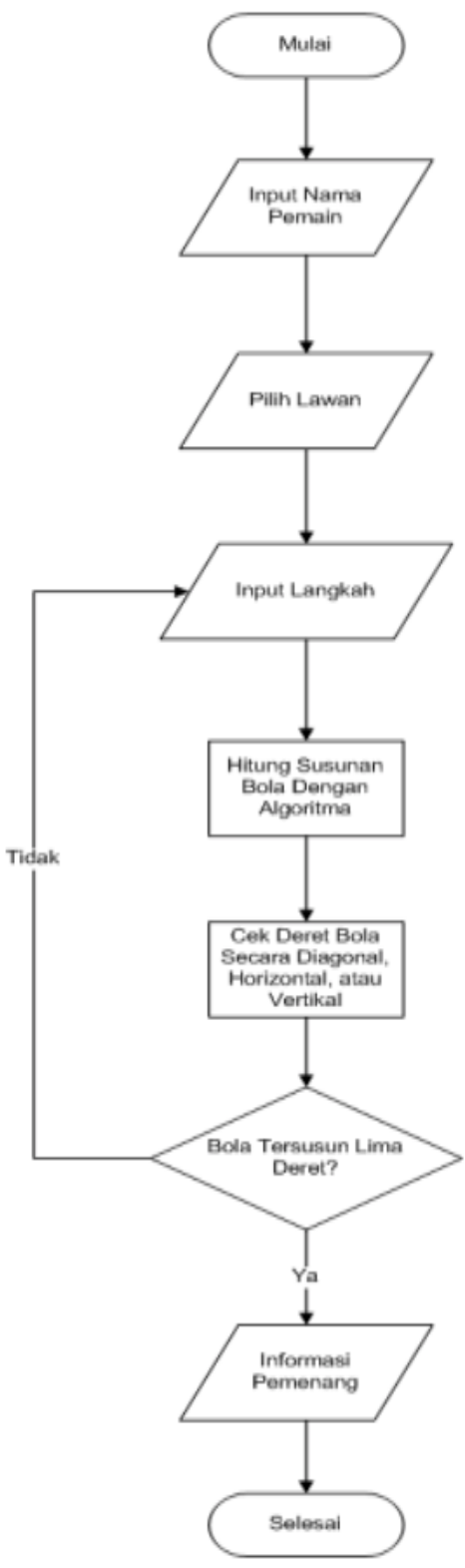

Gambar 4.6 Flowchart Diagram Permainan Deret Lima 


\section{H. Perancangan Antarmuka (interface)}

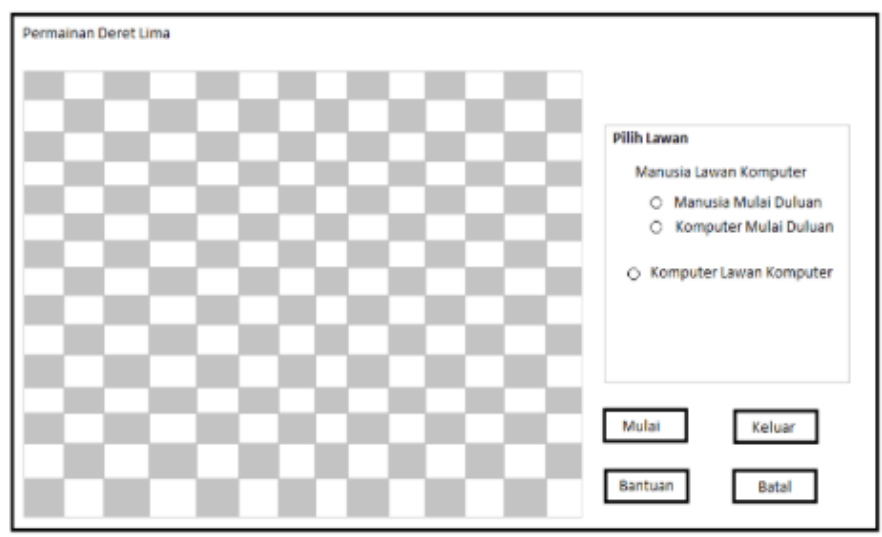

Gambar 4.7 Papan Permainan

\section{Implementasi Antarmuka}

Aplikasi permainan deret lima ini di bangung dengan menggunakan bahasa pemrograman Borland Delphi 7 yang merupakan bahasa pemrograman yang berorientasi object. Berikut adalah beberapa objek-objek yang dipakai pada aplikasi permainan deret lima:

1) Form Utama

Form utama, adalah form awal pada aplikasi permainan deret lima. Berikut tampilan antar muka aplikasi deret lima

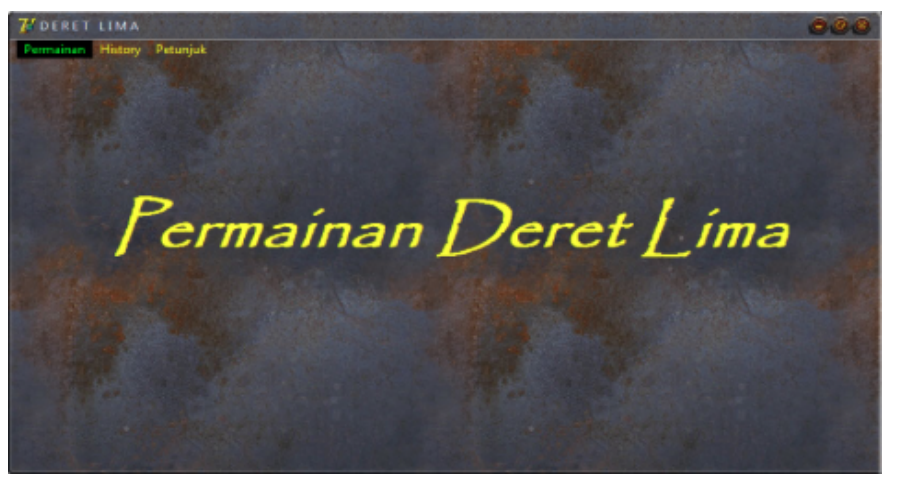

Gambar 4.8 Antar Muka Menu Utama

2) Form Input Nama Pemain

Form input Nama Pemain berfungsi untuk menginputkan nama pemain, sebagai pemain yang memainkan permainan. Berikut detail penjelasan komponen yang menyusun form ini pada tabel di bawah ini

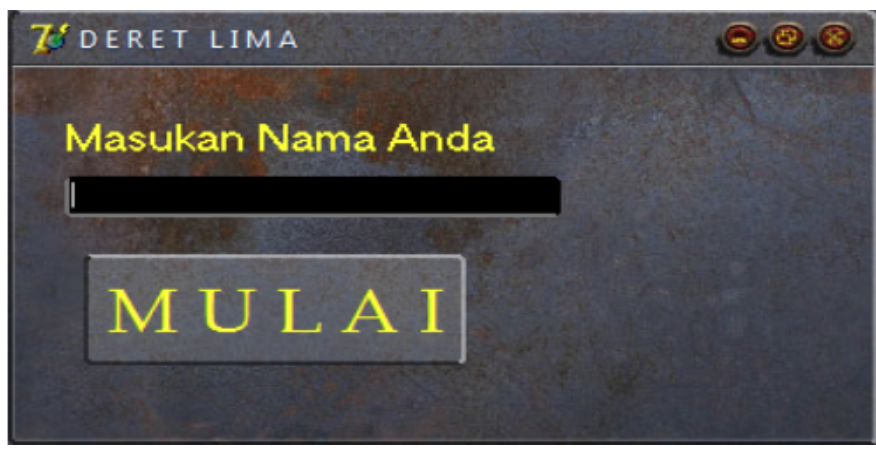

Gambar 4.9 Form Input Nama Pemain

3) Form Papan Permainan

Form papan permainan adalah form area permainan deret lima, di form ini pemain melakukan permainan.

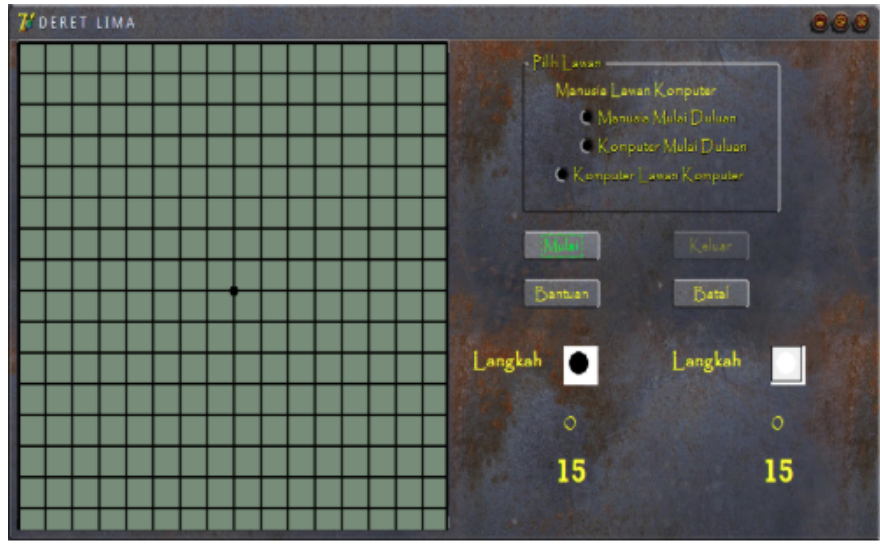

Gambar 4.10 Form Papan Permainan

4) Form Petunjuk Permainan

Form ini berfungsi untuk memberikan informasi cara bermain permainan deret lima. Adapun komponen yang menyusun form ini dapat dilihat pada gambar 4.11 dibawah ini :

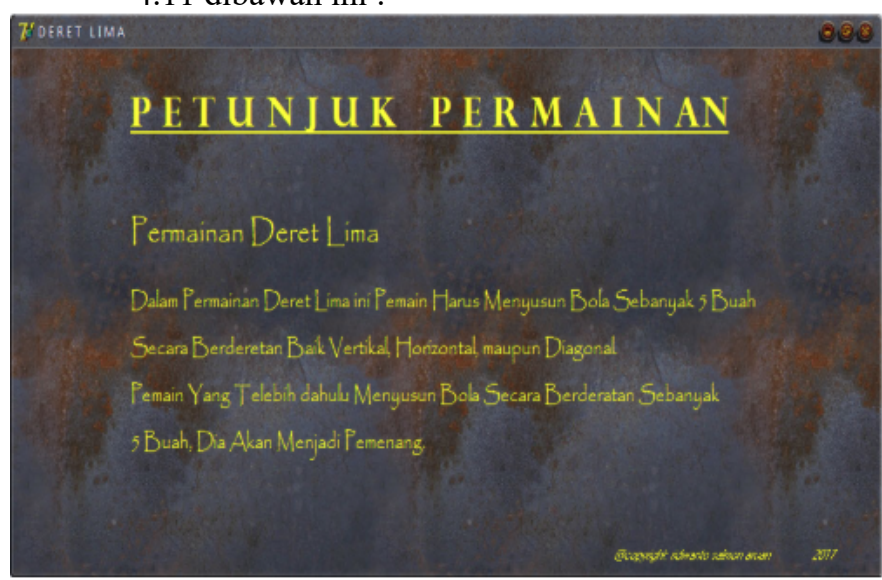

Gambar 4.11 Form Petunjuk Permainan 


\section{KESIMPULAN DAN SARAN}

\section{A. Kesimpulan}

Dari hasil penelitian dan pengujian yang telah dilakukan oleh penulis terhadap aplikasi permainan deret lima maka dapat disimpulkan kelebihan dan kekurangan sebagai berikut:

1) Kelebihan:

a) Algoritma Negamax dapat diterapkan pada aplikasi permainan deret lima untuk menerapkan intelegensia buatan.

b) Aplikasi deret lima dibatasi waktu dalam permainannya yakni 15 detik.

c) Aplikasi permainan deret lima mampu dimainkan oleh computer lawan komputer Aplikasi permainan deret lima memiliki 2) Kekurangan: skala papan permainan 15 X 15 .

a) Pada aplikasi ini tidak menggunakan pengaturan tingkatan kesulitan.

b) Pada aplikasi ini tidak memakai sistem skoring permainan.

c) Pada permainan ini tidak dapat digunakan lebih dari 2(dua) pemain.

B. Saran

Setelah melakukan penelitian dan pengujian pada pembuatan skripsi yang berjudul Penerapan Intelegensi Buatan dengan Algoritma Negamax pada Aplikasi Permainan Deret Lima terdapat beberapa saran yang penulis harapkan untuk menutupi dan untuk kemajuan penelitian selanjut:

1) Diharapkan permainan ini dapat menggunakan pengaturan tingkatan kesulitan.

2) Aplikasi permainan deret lima ini dikembangkan dan diperluas lagi menjadi berbasis client/server maupun android sehingga dapat digunakan lebih dari 2 (dua) pemain.

3) Diharapkan aplikasi ini dapat dikembangkan lagi agar memiliki sistem skoring pada permainan.

\section{UCAPAN TERIMA KASIH}

Di Dalam pengerjaan laporan ini, penulis telah melibatkan banyak pihak yang sangat membantu dalam banyak hal. Oleh sebab itu, disini penulis sampaikan rasa terima kasih sedalamdalamnya kepada :

1) Kepada kedua orang tua tercinta yang selama ini selalu mendoakan dan memberikan dorongan moral dan materiil yang tidak ternilai harganya.

2) Dosen Pembimbing Heti Mulyani, ST, M.Kom dan Bapak Saharudin., S.T atas segala masukan dan sarannya dalam proses penyelesaian pengerjaan penelitian ini.

3) Seluruh Dosen dan Staff Sekolah Tinggi Teknologi Indonesia Tanjungpinang yang telah memberikan banyak ilmu dan motivasi selama melaksanakan studi.

4) Rekan-rekan mahasiswa satu angkatan jurusan komputer akuntansi yang selalu bersatu dalam menjalani masa pendidikan di Sekolah Tinggi Teknologi Indonesia Tanjungpinang ini.

5) Semua pihak baik yang berhubungan langsung maupun tidak langsung yang telah mendukung atas terselesaikannya masa studi kami.

Akhir kata penulis mengucapkan terima kasih, semoga Allah SWT membalas semua kebaikan yang telah diberikan kepada penulis.

\section{REFERENSI}

[1] S. Pressman, Ph. D, 2007, Roger. Rekayasa Perangkat Lunak. Yogyakarta: Andi.

[2] Kristanto, Andri, Kecerdasan Buatan, Yogyakarta: Graha Ilmu, 2004.

[3] Kadir, Abdul \& Terra Ch. Triwahyuni, Pengenalan Teknologi Informasi, Yogyakarta: Andi, 2003.

[4] M.Sc, M.Math, Ph.D, Drs. Suarga, Algoritma Pemrograman,Yogyakarta: Andi, 2006.

[5] Munir, Rinaldi, Algoritma dan Pemrograman, Bandung: Informatika Bandung, 2006.

[6] http://kbbi.web.id/main [23 Feb 2017, 09:45]

[7] https://id.wikipedia.org/wiki/Permainan [23 Feb 2017, 09:46]

[8] Munawar. Pemodelan Visual dengan UMl. Yogyakarta: Graha Ilmu, 2005

[9] Nugroho, Andi, 2004, Analisis Dan Perancangan Sistem Informasi Dengan Metodologi Berorientasi Objek (Edisi Revisi), Bandung: Informatika Bandung,

[10] S. Pressman, Ph. D , Roger. Rekayasa Perangkat Lunak. Yogyakarta: Andi, 2007. 